\title{
RECOVERY OF STREPTOCOCCUS MUTANS AND STREPTOCOCCUS SANGUIS FROM A DENTAL EXPLORER AFTER CLINICAL EXAMINATION OF SINGLE HUMAN TEETH
}

\author{
W. J. Loesche, A. Walenga and P. Loos \\ Department of Oral Biology and Pedodontics, University of Michigan \\ School of Dentistry, Ann Arbor, Michigan 48104, U.S.A.
}

\begin{abstract}
Summary-Certain aspects of the bacterial flora adhering to a dental explorer following a tactile diagnostic examination of a single tooth were investigated. Plaque present on the explorer was dislodged, and suspended into a reduced transport fluid by sonification. After serial dilution, suitable aliquots were placed on a high sucrose-containing medium, and on a mannitol medium. Colonies resembling Streptococcus mutans and Streptococcus sanguis were enumerated on these media. The explorer removed approximately 3-7 $\times 10^{6}$ bacteria from a single tooth. Streptococcus mutans accounted for 17 per cent of the isolates from carious teeth and for 1.6 per cent of the isolates found on noncarious teeth. This difference was significant at the $p<0.01$ level. The proportions of Strep. sanguis were significantly higher in material removed from noncarious teeth than in plaque removed from the carious teeth.
\end{abstract}

Streptococcus mutans is an aetiologic agent of caries in certain animal model-systems (KEYES, 1968). This organism is present in man on a worldwide basis (JoRDAN, ENGLANDER and Lim, 1969; BratTHALL, 1972) and evidence exists linking this organism to active human caries (Krasse et al., 1968; De StOpPelaAR, van Houte and BACKer-DirKs, 1969; WoOds, 1971; Schamschula and Charlton, 1971). The localization of Strep. mutans in the oral cavity is apparently related to the site of the carious lesion. Littleton, KaKehashi and FitzGerald (1970) found Strep. mutans in all carious lesions sampled, but they could recover this organism from only 6 to 26 plaques removed from non-carious teeth. ShKLAIR, KeEnE and Simonson (1972) showed that the prevalence and isolation-frequency of Strep. mutans decreased when plaque samples were obtained from sites distant from a carious lesion. In the present study, the localization of Strep. mutans to carious teeth was confirmed, using media which permitted presumptive identification of Strep. mutans and Strep. sanguis.

A senior dental student was given a sterile dental explorer contained in an autoclaved wrapper. The explorer was unwrapped without touching the curved end, and used to examine a single tooth for caries on any of its surfaces. After completion of this tactile diagnostic examination, the student placed the end of the explorer which had made tooth contact into $10 \mathrm{ml}$ of a filter sterilized reduced transport fluid (RTF, 
LOESCHE, HockeTt and SYED, 1972) which was contained in a centrifuge tube (29 $\times$ $103 \mathrm{~mm}$ ). Three to five deciduous or permanent molars were examined in this manner for each of 17 paedodontic patients during their initial visit to the clinic. The explorers were immediately taken to the laboratory, where the material present on the explorer tip was dislodged by introducing a microprobe into the RTF and subjecting the mixture to sonic oscillation for $10 \mathrm{sec}$ at maximum intensity (Ultrasonics Inc. Model W1850). The dispersed plaque was serially diluted in RTF and aliquots of $0.05 \mathrm{ml}$ of appropriate dilutions were plated in duplicate on MMl0 sucrose agar and on a mannitol agar medium. The plates were incubated anaerobically for 4-5 days in an anaerobic chamber under an 85 per cent $\mathrm{N}_{2}, 10$ per cent $\mathrm{H}_{2}$ and 5 per cent $\mathrm{CO}_{2}$ atmosphere. Colonies were examined under a dissecting microscope, and those resembling Strep. mutans and Strep. sanguis enumerated and expressed as a percentage of the total number of colonies present.

MM10 sucrose agar is a non-selective medium which has a high carbohydrate to nitrogen ratio, thereby permitting the easy identification of polysaccharide-forming isolates such as Strep. mutans and Strep. sanguis. The composition of MM10 sucrose agar is: 1.5 per cent agar, 0.2 per cent trypticase, 0.05 per cent yeast extract, 0.024 per cent $\mathrm{K}_{2} \mathrm{HPO}_{4}, 0.024$ per cent $\mathrm{KH}_{2} \mathrm{PO}_{4}, 0.045$ per cent $\mathrm{NaCl}, 0.04$ per cent $\left(\mathrm{NH}_{4}\right)_{2} \mathrm{SO}_{4}, 0.009$ per cent $\mathrm{MgSO}_{4}, 0.025$ per cent $\mathrm{KNO}_{3}, 0.1 \mathrm{mg}$ per cent haemin, 0.15 per cent $\mathrm{Na}$ lactate, 0.1 per cent $\mathrm{Na}$ formate and 5 per cent sucrose. After autoclaving the above, the following filter-sterilized compounds were aseptically added: 0.1 per cent glucose, 0.04 per cent $\mathrm{Na}_{2} \mathrm{CO}_{3}, 0.01$ per cent dithiothreitol, and menadione $0.5 \mu \mathrm{g} / \mathrm{ml}$. Sterile 2 per cent sheep blood was the final addition. On this medium, Strep. mutans forms an irregular, heaped, tacky colony, which sometimes exhibits a glistening bubble on its surface, or a pooling of liquid around its periphery. Streptococcus sanguis forms several types of hard, clear and adherent colonies. Representative Strep. mutans isolates were checked for mannitol fermentation, and for plaque formation on wires in sucrose broth.

The mannitol medium permitted growth of amino acid and mannitol-fermenting isolates. Species such as Strep. mutans and Lactobacillus casei could be identified by their yellow colony due to acid formation from mannitol. The amino acid fermenters did not lower the $\mathrm{pH}$ and, therefore, had the purple colour of the medium. The composition of the mannitol medium is: 1.5 per cent thioglycollate medium without dextrose (Difco), 1 per cent mannitol, 0.05 per cent glucose and 0.002 per cent bromocresol purple. The small amount of glucose added seemed to favour growth of Strep. mutans, presumably by acting as an energy source for the induction of the enzymes needed for mannitol metabolism.

The teeth were grouped according to the presence or absence of caries. The explorer examination performed by both a student and an instructor revealed detectable "catches" on 33 teeth, indicating either carious lesions or developmental defects, and no catches on another 28 teeth. Bitewing radiographs revealed carious lesions in four of the teeth without catches, and the absence of lesions in one tooth diagnosed by the explorer as having a catch. These teeth were reclassified giving a total of 36 clinically carious teeth and 25 non-carious teeth which were included in this study. 
The dental explorer removes varying amounts of plaque depending upon: (1) the actual plaque mass present, (2) the size of the tooth, (3) whether the tooth is carious or not, and (4) the thoroughness of the examiner. In the present study, the recoveries ranged from $0.05 \times 10^{6}$ to $60 \times 10^{6}$ bacteria per sample. Approximately $3 \cdot 2 \pm 5 \cdot 6 \times 10^{6}$ bacteria were removed from each carious tooth and $7 \cdot 3 \pm 12 \cdot 3 \times$

Table 1. Occurrence of Streptococcus mutans on Carious and NON-CARIOUS TEETH

\begin{tabular}{lccc}
\hline & \multicolumn{2}{c}{ Clinical diagnosis* } & \\
\cline { 2 - 3 } & Caries & No caries & Total \\
\hline $\begin{array}{c}\text { Strep. mutans } \\
\text { present } \\
\begin{array}{c}\text { Strep. mutans } \\
\text { not detected }\end{array}\end{array}$ & $30(21) \dagger$ & $5(14)$ & 35 \\
\hline Total & 36 & $20(11)$ & 26 \\
\hline
\end{tabular}

- Based upon explorer examination and X-ray interpretation.

+ Expected values are in parenthesis, chi-square $=22 \cdot 1, P<0.01$.

$10^{6}$ bacteria from each non-carious tooth. Strep. mutans was a conspicuous isolate from carious teeth, being present in 30 of 36 teeth examined (Table 1). This organism was found in plaque from only five of the 25 non-carious teeth. This distribution frequency was not what would be expected by chi-square analysis and suggested that the association of Strep. mutans with carious teeth was statistically significant

TAble 2. Percentage Recovered of Strep. mutans AND Strep. sanguis From CARIOUS AND NON-CARIOUS TEETH

\begin{tabular}{lccc}
\hline & Carious teeth $(n=36)$ & Non-carious teeth $(n=25)$ \\
\hline $\begin{array}{l}\text { Strep. mutans as \% of } \\
\text { total counts* }\end{array}$ & $17.2+21.3 \dagger$ & $p<0.01 \ddagger$ & $1.6+5.5$ \\
$\begin{array}{c}\text { Strep. sanguis as \% of } \\
\text { total count* }\end{array}$ & $4.7+5.4$ & $p<0.05 \ddagger$ & $9.5+8.8$ \\
$\begin{array}{c}\text { Ratio } \\
\text { Strep. mutans }\end{array}$ & 3.6 & & \\
\hline Strep. sanguis & & 0.16 \\
\hline
\end{tabular}

- Total count on MM10 sucrose agar; 4-5 day anerobic incubation.

$t$ Mean plus or minus standard deviation.

$\$$ Statistically significant by student $t$-test.

(chi-square $=22 \cdot 1, p<0.01$, Table 1). The percentage of Strep. mutans and Strep. sanguis present of the total bacterial counts obtained from each tooth was calculated (Table 2). Strep. mutans accounted for 17 per cent of the isolates from the caries active teeth. This level was significantly higher than the 1.6 per cent level found for the caries free teeth, and confirms the finding that Strep. mutans is localized to carious teeth. Conversely, the proportions of Strep. sanguis were significantly higher on noncarious teeth (Table 2). This negative association of St:ep. sanguis with caries had been noted by DE STOPPELAAR et al. (1969) in man, and by BowEN (1965) in macaque 
monkeys. When the ratio of percentage Strep. mutans to percentage Strep. sanguis was calculated, the carious teeth had a value of $3 \cdot 6$, whereas the non-carious teeth had a value of only $0 \cdot 16$. This ratio might be of diagnostic value in the bacteriological analysis of the caries status of a tooth or teeth.

In those teeth harbouring Strep. mutans, the counts of Strep. mutans on the MM10 sucrose medium was $0.68 \times 10^{6}$, whereas the number of Strep. mutans on the mannitol medium was $0.55 \times 10^{6}$. This difference was not significant and indicated that the data obtained from both media were similar. The use of two diagnostic media for the primary isolation of Strep. mutans has certain advantages: (1) the media can be used to confirm each other, (2) the purple mannitol plates can be readily screened for yellow colonies, thereby indicating which samples have Strep. mutans, (3) two characteristics of Strep. mutans are tested for in primary isolation, i.e. polysaccharide formation by MM10 sucrose and mannitol fermentation by the mannitol medium, so that if samples are positive for both characteristics, a presumptive identification of Strep. mutans can be made.

The data show that, from teeth with carious lesions, large numbers of Strep. mutans can be picked up by a dental explorer. This raises the possibility that the explorer after contacting a single carious tooth can serve to inoculate other teeth in the same mouth with Strep. mutans during a routine diagnostic examination. Such a mechanism of spread for Strep. mutans might be important, as it appears that this organism does not readily seed itself throughout the oral cavity. When streptomycin-resistant Strep. mutans were implanted on the right side of the dental arch of two volunteers, the labelled organisms were recovered in 83 of 163 samplings from the implanted side, but in only three of the 126 samplings from the left or unimplanted side over a 4-6 month period of observation (EDMAN et al., 1972). Further studies are needed to determine if Strep. mutans is actually spread by an explorer, and what significance this may have on the subsequent caries experience of the teeth involved.

Acknowledgement-This investigation was supported by grant DE-03011 from the National Institute of Dental Research.

Résumé-On a investigué certains aspects de la flore bactérienne adhérant à un explorateur dentaire, suivant un examen diagnostique tactile d'une seule dent. On a délogé la plaque présente sur l'explorateur et on l'a suspendue dans un liquide de transport, réduit par sonification. Après des dilutions en séries, des aliquotes convenables ont été placées dans un milieu contenant de la sucrose en grande quantité et dans un milieu de mannitol. On a compté dans ces milieux des colonies ressemblant au Streptococcus mutans et au Streptococcus sanguis. L'explorateur enleva d'une seule dent environ $3-7 \times 10^{6}$ bactéries. Le streptococcus mutans représentait 17 pour cent des bactéries isolées des dents cariées et 1,6 pour cent des bactéries trouvées sur les dents non-cariées. Cette différence était significative au niveau $p<0,01$. Les proportions du Strep. sanguis étaient significativement plus grandes dans le matériel retiré des dents non-cariées que dans la plaue retirée des dents cariées.

Zusammenfassung-Es wurden bestimmte Richtungen der Bakterienflora, welche an einer Zahnsonde anhängt, nach einer taktilen, diagnostischen Untersuchung an einem einzelnen Zahn geprüft. An der Sonde vorhandene Plaque wurde entfernt und durch 
Lärm machen in einer abgeschwächten Transportflüssigkeit suspendiert. Nach reihenmässiger Auflösung wurden geeignete Aliquoten auf ein viel Saccharose enthaltendes und auf ein Mannitmittel gelegt. Es wurden Kolonien ähnlich dem Streptococcus mutans und dem Streptococcus sanguis auf diesen Mitteln gezählt. Die Sonde entfernte etwa 3-7 $\times 10^{6}$ Bakterien von einem einzelnen Zahn. Streptococcus mutans war für 17 Prozent der Absonderungen von kariösem Zahn und für 1,6 Prozent Absonderungen verantwortlich, welche an nicht kariösem Zahn gefunden wurden. Dieser Unterschied war bei dem $p<0,01$ Stand bezeichnend. Die verhälnismässigen Mengen des Strep. sanguis waren bei Material aus nicht kariösen'Zähnen erheblich grösser als in der Plaque, welche aus kariösen Zähnen entfernt worden war.

\section{REFERENCES}

BOWEN, W. H. 1965. A bacteriological study of experimental dental caries in monkeys. Int. dent. J. $15,12-53$.

Bratthall, D. 1972. Demonstration of Streptococcus mutans strains in some selected areas of the world. Odont. Revy 23.

DE StoppelaAr, J. D., VAN Houte, J. and Backer-Dirks, O. 1969. The relationship between extracellular polysaccharide producing streptococci and smooth surface caries in 13-year-old children. caries Res. 3, 190-199.

Edman, D. C., Keene, H. J., ShKlair, I. L. and Hoerman, K. C. 1972. Dental floss for interproximal implantation and sampling of Streptococcus mutans. Preprinted Abstract Int. Assoc. Dent. Res. General Meeting, Abstract 73.

Jordan, H. V., Englander, H. R. and Lim, S. 1969. Potentially cariogenic streptococci in selected population groups in the western hemisphere. J. Am. dent. Ass. 78, 1331-1335.

KeYeS, P. H. 1968. Research in dental caries. J. Am. dent. Ass. 72, 1357-1373.

Krasse, B., Jordan, H. V., Edwardsson, S. and TreLl, L. 1968. The occurrence of certain "cariesinducing" streptococci in human dental plaque material with special reference to frequency and activity of caries. Archs oral Biol. 13, 911-918.

Littleton, N. W., Kakehashi, S. and FitzGerald, R. J. 1970. Recovery of specific "caries-inducing" streptococci from carious lesions in the teeth of children. Archs oral Biol. 15, 461-464.

Loesche, W. J., Hockett, R. N. and Syed, S. A. 1972. The predominant cultivable flora of tooth surface plaque removed from institutionalized subjects. Archs oral Biol. 17, 1311-1325.

Schamschula, R. G. and Charlton, G. 1971. A study of caries etiology in New South Wales school children. I. The streptococcal flora of plaque and caries prevalence. Aust. dent. J. 16, 77-82.

ShKLAIR, I. L., KeENE, H. J. and Simonson, L. G. 1972. Distribution and frequency of Streptococcus mutans in caries active individuals. J. dent. Res. $51,882$.

Woods, R. 1971. A dental caries susceptibility test based on the occurrence of Streptococcus mutans in plaque material. Aust. dent. J. 16, 116-121. 